\title{
INFLUENCE OF FIVE CLONAL ROOTSTOCKS ON THE GROWTH, PRODUCTIVITY AND FRUIT QUALITY OF 'SYLVIA' AND 'KARINA' SWEET CHERRY TREES
}

\author{
Mirosław Sitarek and Barbara Bartosiewicz \\ Research Institute of Horticulture \\ Konstytucji 3 Maja 1/3, 96-100 Skierniewice, POLAND \\ e-mail: miroslaw.sitarek@inhort.pl
}

(Received August 3, 2012/Accepted October 17, 2012)

\section{A B S T R A C T}

In the field experiment, 8-year-old 'Sylvia' and 'Karina' sweet cherry trees grafted on 'GiSelA 3', 'GiSelA 5', 'Piku 4'and 'Weiroot 72' clonal rootstocks were compared with trees of the same cultivars on the standard rootstock F 12/1. The data collected included tree vigour (expressed as trunk cross-sectional area - TCSA), yield, and fruit weight as well as content of soluble solids in fruit.

Based on TCSA, the largest 'Sylvia' and 'Karina' trees were on 'F12/1', and the smallest were on 'GiSelA 3'. The results revealed that all of the tested rootstocks being compared to ' $\mathrm{F} 12 / 1$ ', significantly reduced the growth of sweet cherry trees.

'Sylvia' trees on 'GiSelA 5' and 'Piku 4' yielded more than those on 'F12/1'. The highest cumulative yields of 'Karina' were harvested from trees on 'GiSelA 5'. 'Karina' trees on 'GiSelA 3', 'Piku 4' and 'Weiroot 72' performed comparably in cumulative yields to those on 'F12/1'. Rootstock effects on yield efficiency were consistent between the two cultivars, with the most yield efficient trees on 'GiSelA 3', 'GiSelA 5' and 'Weiroot 72', and the least efficient trees on 'F12/1'.

Trees of both cultivars grafted on 'GiSelA 3' produced significantly smaller fruits than those grafted on ' $\mathrm{F} \mathrm{12/1}$ '. The rest of the rootstocks, tested in terms of an effect on fruit weight (with the exception of 'Karina' on 'Weiroot 72'), had a similar value to 'F $12 / 1$ '. Effects of rootstock on content of soluble solids in fruit were modest and statistically insignificant.

Key words: yield, vigour, dwarfing effect, fruit weight, content of soluble solids 


\section{INTRODUCTION}

The rootstock is a critical component of any orchard management system. The introduction of dwarfing cherry rootstocks and newer cultivars has allowed new possibilities for developing high-density sweet cherry orchards. Such orchards would have smaller trees that would be more precocious and productive (Lang, 2000; Robinson, 2005). Various breeding programs around the world have released a number of new rootstocks. Some of these rootstocks have resulted from interspecific hybrids and others are selections within a species (Hrotkó, 2008). Many of these rootstocks are presently being tested in different soil and climate conditions around the world (Kappel and Lang, 2008; Lugli and Sansavini, 2008; Stehr, 2008; Usenik et al., 2008).

Investigations of clonal sweet cherry rootstocks having different vigour began in Poland in 1988. Results of those experiments with ' $\mathrm{P}$ HL A', 'P-HL C', 'Colt' and 'Maxma 14' rootstocks have already been published by Grzyb et al. (1998, 2005) and Sitarek et al. (1999). In the next few years, new trials were planted to test some of the successive rootstocks 'P-HL B', 'Tabel Edabriz', 'Weiroot 158' and 'GiSelA 5' used for 'Vanda' and 'Kordia' sweet cherry cultivars (Grzyb et al., 2008; Sitarek and Grzyb, 2010). The objective of this study was to evaluate 'GiSelA 3', 'GiSelA 5', 'Piku 4'and 'Weiroot 72' rootstocks in comparison to ' $\mathrm{F} 12 / 1$ '. The trial included 'Sylvia' and 'Karina' as the scion cultivars.
MATERIAL AND METHODS

For eight consecutive years in the Experimental Orchard in Dąbrowice, near Skierniewice, Poland, growth, yield and fruit quality of 'Sylvia' and 'Karina' sweet cherry trees grafted on 'F12/1' - as a control, 'GiSelA 3', 'GiSelA 5', 'Piku 4' and 'Weiroot 72' clonal rootstocks were investigated. One-year-old trees were planted in the spring of 2004, in grey-brown podzolic soil at a distance of $5 \times 2.75 \mathrm{~m}$ (at 727 trees/ha). The experimental design was a randomized complete block with four blocks and three trees representing each cultivar/rootstock combination in a block. Trees were trained to a vertical axis system. In 2004 and 2005 , the soil was kept free from weeds by mechanical cultivation. During the following years soil management included frequent grass mowing in the alleyways and maintenance of 1-m-wide herbicide strips along the tree rows. The experimental orchard was irrigated. Fertility, pest and disease control were per Polish recommendations for commercial sweet cherry orchards. To prevent damage by birds, Bird Gard Super Pro by Weitech was used.

Trunk circumference, $25 \mathrm{~cm}$ above the bud union, was measured annually in October and transformed to trunk cross-sectional area (TCSA). Due to spring frost in 2007, trees of both cultivars were not fruiting. Yield per tree was assessed in 20082011 as total weight of the harvested fruit. Cumulative yield efficiency was calculated as cumulative yield 
(2008-2011) divided by TCSA, in 2011. Fruit weight, in every year of the investigation, was derived from $5 \mathrm{~kg}$ fruit samples taken from each block. The average fruit weight (2008-2011) was calculated. The content of soluble solids in fruit was measured by portable optical refractometer PZO RR12 in each year of the four years of yielding, using 25 fruit taken from each block.

Data were analysed separately for each cultivar using statistical analysis of variance. Rootstock means were separated by Duncan's Multiple Range test at $\mathrm{p} \leq 0.05$.

\section{RESULTS}

Based on TCSA, the largest 'Sylvia' and 'Karina' trees were on 'F12/1', and the smallest were on 'GiSelA 3'. The results revealed that all rootstocks tested in comparison to ' $F$ 12/1', significantly reduced the growth of sweet cherry trees (Tab. 1).

'Sylvia' trees on 'GiSelA 5' and 'Piku 4' yielded more than those on 'F12/1'. The highest cumulative yields of 'Karina' were harvested from trees on 'GiSelA 5'. 'Karina' trees on 'GiSelA 3', 'Piku 4' and 'Weiroot 72' performed comparably in cumulative yields, to those on 'F12/1'. However, trees of both cultivars yielded less than expected due to spring frost in 2007.

Rootstock effects on yield efficiency were consistent between the two cultivars, with the most yield efficient trees on 'GiSelA 3', 'GiSelA 5' and 'Weiroot 72', and the least efficient trees on 'F12/1' (Tab. 1).

Table 1. Effect of rootstock on trunk cross-sectional area, yield and fruit quality of 8-year-old 'Sylvia' and 'Karina' sweet cherry trees

\begin{tabular}{|c|c|c|c|c|c|c|c|}
\hline \multirow{2}{*}{ Rootstock } & \multicolumn{2}{|c|}{$\begin{array}{c}\text { Trunk cross-sectional } \\
\text { area } \\
2011 \\
\end{array}$} & \multicolumn{3}{|c|}{$\begin{array}{c}\text { Cumulative yield } \\
\text { 2008-2011 }\end{array}$} & \multirow{2}{*}{$\begin{array}{c}\text { Mean } \\
\text { fruit } \\
\text { weight } \\
2008- \\
2011 \\
{[\mathrm{~g}]} \\
\end{array}$} & \multirow{2}{*}{$\begin{array}{c}\text { Content of } \\
\text { soluble } \\
\text { solids in } \\
\text { fruit } \\
2008-2011 \\
{[\%]}\end{array}$} \\
\hline & {$\left[\mathrm{cm}^{2}\right]$} & $\begin{array}{l}{[\%] \text { of }} \\
\text { F12/1 }\end{array}$ & [kg/tree] & $\begin{array}{c}{\left[\mathrm{kg} / \mathrm{cm}^{2}\right.} \\
\text { TCA }]\end{array}$ & [t/ha] & & \\
\hline \multicolumn{8}{|c|}{ Sylvia } \\
\hline F12/1 & $204.9 \mathrm{e}^{*}$ & 100.0 & $40.0 \mathrm{a}$ & $0.19 \mathrm{a}$ & 29.1 & $8.96 \mathrm{~b}$ & $15.1 \mathrm{a}$ \\
\hline GiSelA 5 & $93.4 \mathrm{c}$ & 45.6 & $62.1 \mathrm{bc}$ & $0.66 \mathrm{c}$ & 45.1 & $8.80 \mathrm{~b}$ & $15.4 \mathrm{a}$ \\
\hline GiSelA 3 & $64.4 \mathrm{a}$ & 31.4 & $49.4 \mathrm{ab}$ & $0.77 \mathrm{~d}$ & 35.9 & $7.96 \mathrm{a}$ & $15.3 \mathrm{a}$ \\
\hline Piku 4 & $155.9 \mathrm{~d}$ & 76.1 & $67.9 \mathrm{c}$ & $0.44 \mathrm{~b}$ & 49.4 & $8.86 \mathrm{~b}$ & $15.7 \mathrm{a}$ \\
\hline Weiroot 72 & $75.6 \mathrm{~b}$ & 36.9 & $52.0 \mathrm{ab}$ & $0.69 \mathrm{c}$ & 37.8 & $8.85 \mathrm{~b}$ & $15.5 \mathrm{a}$ \\
\hline \multicolumn{8}{|c|}{ Karina } \\
\hline $\mathrm{F} 12 / 1$ & $294.1 \mathrm{~d}$ & 100.0 & $76.8 \mathrm{a}$ & $0.26 \mathrm{a}$ & 55.8 & $9.00 \mathrm{c}$ & $15.6 \mathrm{a}$ \\
\hline GiSelA 5 & $185.8 \mathrm{~b}$ & 63.2 & $108.1 \mathrm{~b}$ & $0.58 \mathrm{c}$ & 78.6 & $8.54 \mathrm{bc}$ & $15.9 \mathrm{a}$ \\
\hline GiSelA 3 & $101.1 \mathrm{a}$ & 34.4 & $73.8 \mathrm{a}$ & $0.73 \mathrm{~d}$ & 53.7 & $8.04 \mathrm{a}$ & $16.2 \mathrm{a}$ \\
\hline Piku 4 & $236.6 \mathrm{c}$ & 80.4 & $87.1 \mathrm{a}$ & $0.37 \mathrm{~b}$ & 63.3 & $8.92 \mathrm{c}$ & $16.5 \mathrm{a}$ \\
\hline Weiroot 72 & $104.7 \mathrm{a}$ & 35.6 & 83.9 a & $0.80 \mathrm{~d}$ & 61.0 & $8.25 \mathrm{ab}$ & $15.8 \mathrm{a}$ \\
\hline
\end{tabular}

*Mean separation within column and cultivar by Duncan's Multiple Range test at $\mathrm{p} \leq 0.05$ 
Trees of both cultivars grafted on 'GiSelA 3' produced significantly smaller fruits than those grafted on ' $F 12 / 1$ '. The rest of the rootstocks tested in terms of an effect on fruit weight (with the exception of 'Karina' on 'Weiroot 72'), had a similar value as ' $F$ 12/1'. Effects of rootstock on content of soluble solids in fruit were modest and statistically insignificant.

After eight growing seasons, it was shown that the rootstock did not affect survival of 'Sylvia' and 'Karina' trees. No tree decline and no incompatibility symptoms between rootstock and scion were found. Root suckering was not a problem in this trial.

\section{DISCUSSION}

Our results after 8 years show the strong effect of rootstock on the growth, yield, and fruit weight of sweet cherry trees. However, no significant effect of rootstock on the content of soluble solids in fruit was found. Rootstocks 'GiSelA 5', 'GiSelA 3', 'Piku 4' and 'Weiroot 72 ' significantly reduced the tree growth in comparison to the standard ' $F$ 12/1'. In some previous studies, the same rootstocks - in terms of vigour, performed similarly (FrankenBembenek, 2005; Grzyb et al., 2008; Kappel and Lang 2008; Sitarek and Grzyb, 2010). In our experiment, 'GiSelA 3' and 'Weiroot 72' with both scion cultivars, proved to be the most dwarfing rootstocks. In a Northern Germany rootstock trial, the 'Kordia' sweet cherry trees grafted on
'Weiroot 72' and 'GiSelA 3' were also very dwarfing (Stehr, 2008).

With cumulative yield and cumulative yield efficiency, rootstock effects were efficient. Trees of 'Sylvia' on 'GiSelA 5' and 'Piku 4' yielded higher than those on 'F12/1'. 'Karina' trees yielded higher on 'GiSelA 5' than on other rootstocks tested. The relative effects of rootstock on cumulative yield efficiency were mostly consistent with tree vigour. Rootstocks that strongly reduced tree growth also had high cumulative yield efficiency. Such a finding is not surprising since many reports state that productivity of sweet cherry trees is affected by rootstock type (Franken-Bembenek, 2005; Sitarek et al. 2005; Sitarek and Grzyb, 2010; Stehr, 2008).

In this trial, trees grafted on 'GiSelA 3' had the lowest trunk crosssection area and produced smaller fruits than trees on the 'F12/1' standard rootstock. Usually, those rootstocks that very effectively reduce tree growth also have smaller fruits (De Salvador et al., 2005; Grzyb et al., 1998; Sansavini and Lugli, 1998; Sitarek and Grzyb, 2010).

Fruit from all trees of each cultivar in every year of yielding were harvested on the same day. No significant effect of rootstock on content of soluble solids in fruit was found.

\section{CONCLUSIONS}

1. All rootstocks tested in comparison with 'F12/1', effectively reduced tree size (expressed by TCSA). 
'GiSelA 3' and 'Weiroot 72' proved to be the most dwarfing.

2. Rootstock greatly influenced cumulative yield. 'Sylvia' trees were most productive on 'Piku 4', and 'Karina' on 'GiSelA 5'.

3. Rootstock had a differential effect on the average fruit weight of cultivars tested. In this trial, 'GiSelA 3' produced the smallest fruit and cannot be recommended for commercial sweet cherry orchards.

4. The content of soluble solids in fruit was not affected by rootstock.

\section{REFERENCES}

De Salvador F.R., Di Tommaso G., Piccioni C., Bonofiglio P. 2005. Performance of new and standard cherry rootstocks in different soils and climatic conditions. ACTA HORT. 667: 191-199.

Franken-Bembenek S. 2005. Gisela 5 rootstock in Germany. ACTA HORT. 667: 167-172.

Grzyb Z.S., Sitarek M., Guzowska-Batko B. 2005. Results of a sweet cherry rootstock trial in Northern Poland. ACTA HORT. 667: 207-210.

Grzyb Z.S., Sitarek M., Koziński B. 2008. Evaluation of new rootstocks for 'Vanda' sweet cherry in Polish climatic conditions. ACTA HORT. 795: 215-219.

Grzyb Z.S., Sitarek M., Omiecińska B. 1998. Growth and fruiting of five sweet cherry cultivars on dwarfing and vigorous rootstocks. ACTA HORT. 468: 333-338.

Hrotkó K. 2008. Progress in cherry rootstock research. ACTA HORT. 795: 171-178.
Kappel F., Lang G. 2008. Performance of the NC-140 regional sweet cherry rootstock trial planted in 1998 in North America. ACTA HORT. 795: 317-320.

Lang G.A. 2000. Precocious, dwarfing, and productive - how will new cherry rootstocks impact the sweet cherry industry? HORT. TECHNOL. 10: 719-725.

Lugli S., Sansavini S. 2008. Preliminary results of a cherry rootstock trial in Vignola, Italy. ACTA HORT. 795: 321-326.

Robinson T.L. 2005. Developments in high density sweet cherry pruning and training systems around the world. ACTA HORT. 667:269-272.

Sansavini S., Lugli S. 1998. Performance of V-trained cherry orchard with new dwarf rootstocks. J. FRUIT ORNAM. PLANT RES. 1: 23-31.

Sitarek M., Grzyb Z.S., Czynczyk A., Omiecińska B. 1999. Growth and fruiting of sweet cherry trees grafted on various rootstocks or treated with Cultar. J. FRUIT ORNAM. PLANT RES. 8: 11-17.

Sitarek M., Grzyb Z.S., Omiecińska B. 2005. Performance of sweet cherry trees on Gisela 5 rootstock. ACTA HORT. 667: 389-191.

Sitarek M., Grzyb Z.S., 2010. Growth, productivity and fruit quality of 'Kordia' sweet cherry trees on eight clonal rootstocks. J. FRUIT ORNAM. PLANT RES. 18(2): 169176.

Stehr R. 2008. Further experiences with dwarfing sweet cherry rootstocks in Northern Germany. ACTA HORT. 795: 185-190.

Usenik V., Štampar F., Fajt N. 2008. Sweet cherry rootstock testing in Slovenia. ACTA HORT. 795: 273-276. 


\title{
WPŁYW PIĘCIU PODKŁADEK WEGETATYWNYCH NA WZROST, OWOCOWANIE I JAKOŚĆ OWOCÓW CZEREŚNI 'SYLVIA' I 'KARINA'
}

\author{
Mirosław Sitarek i Barbara Bartosiewicz
}

\author{
S T R E S Z C Z E N I E
}

W doświadczeniu polowym założonym wiosną 2004 roku w Sadzie Doświadczalnym w Dąbrowicach przez osiem kolejnych lat badano wzrost, owocowanie i jakość owoców czereśni 'Sylvia' i 'Karina' zaszczepionych na podkładkach F12/1, GiSelA 3, GiSelA 5, Piku 4 i Weiroot 72. Pomiary grubości pni wykazały, że drzewa obydwu badanych odmian czereśni najsilniej rosły na standardowej podkładce kontrolnej F12/1, a najsłabiej na GiSelA 3. Generalnie, wszystkie oceniane podkładki w porównaniu z 'F12/1' istotnie ograniczały siłę wzrostu drzew.

Z czereśni 'Sylvia' zaszczepionych na 'GiSelA 5' i 'Piku 4' zebrano istotnie wyższe plony owoców niż z drzew na 'F12/1'. Drzewa 'Karina' owocowały najlepiej na podkładce GiSelA 5. Plonowanie drzew tej odmiany na pozostałych podkładkach było porównywalne $\mathrm{z}$ drzewami rosnącymi na standardowej podkładce F12/1. W przypadku obydwu odmian wartość wskaźnika intensywności owocowania obliczonego dla drzew szczepionych na 'GiSelA 3', 'GiSelA 5' i 'Weiroot 72' była wyższa niż dla drzew kontrolnych. Podkładka GiSelA 3 powodowała drobnienie owoców. Nie stwierdzono istotnego wpływu podkładek na poziom ekstraktu w owocach czereśni.

Słowa kluczowe: czereśnia, podkładka, wzrost, owocowanie, jakość owoców 